\title{
Coronavirus Vaccine Distribution: Moving to a Race Conscious Approach for a Racially Disparate Problem
}

\author{
James H. Johnson $\mathrm{Jr}^{1}$ • Jeanne Milliken Bonds ${ }^{1}$ - Allan M. Parnell ${ }^{2} \cdot$ Cedric M. Bright $^{3}$ (D)
}

Received: 25 January 2021 / Revised: 23 April 2021 / Accepted: 26 April 2021 / Published online: 4 May 2021

(C) W. Montague Cobb-NMA Health Institute 2021

\begin{abstract}
Strikingly ignoring the critical impact of systemic racism in vulnerabilities to the deadly coronavirus, phase one of the vaccine rollout is not reaching the Black population that has suffered the most from COVID. An urgent need exists for a race-conscious approach that ensures equitable opportunities to both access and receive the vaccines.
\end{abstract}

Keywords Blacks · COVID-19 · Poverty $\cdot$ Legacy pollutants $\cdot$ Hyper-segregation $\cdot$ Comorbidities $\cdot$ Race-blind vaccine rollout · Reputational equity

Considerable scholarly analysis and media attention have documented the racially disparate impact of coronavirus infections, hospitalizations, and deaths [1-3]. Constituting 13\% of the general population, Blacks reportedly account for $25 \%$ of those that have tested positive and $39 \%$ of the COVID-related deaths in the USA [4].

The over-representation of Blacks in rates of coronavirus infection and deaths is even higher in some states and cities [5]. In Michigan, for example, Blacks make up 14\% of the population but $40 \%$ of COVID-related deaths [6]. In New Orleans, while making up less than one-third of the general population, Blacks "account for almost 60 percent of the COVID-related deaths" [7].

Cedric M. Bright

BRIGHTC19@ecu.edu

James H. Johnson, Jr

Jim_johnson@unc.edu

Jeanne Milliken Bonds

Jeanne_Bonds@kenan-flagler.unc.edu

Allan M. Parnell

allanmparnell@gmail.com

1 Kenan-Flagler Business School, University of North Carolina at Chapel Hill, Chapel Hill, NC 27599, USA

2 Cedar Grove Institute for Sustainable Communities, 619 Lee Street, Mebane, NC 27302, USA

3 Brody School of Medicine, East Carolina University, Greenville, NC 27829, USA
Yet, we have embraced, in all likelihood unconsciously, a race blind approach to phase one vaccine rollout, focusing primarily on two crucial variables - age and occupation - to prioritize the distribution [8]. Strikingly, we are ignoring the critical impact of systemic racism in vulnerabilities to the deadly virus [9]. In so doing, these race blind vaccine rollouts are not reaching the Black population that has suffered most from COVID.

In the phase one rollout, essential healthcare workers and adults 75 or older (recently expanded to include those 65 or older) receive priority for vaccinations. This approach would make perfect sense if our society were equitable and just. Unfortunately, it is not and has never been. Therefore, there is an urgent need to create a racial equity approach to vaccine rollout [10].

The demographic make-up of the US senior population illustrates the nature of the problem with the current roll out strategy [11]. In 2019, Whites made up 76\% of the nation's 65 and older population, exceeding their share of the total population $(60 \%)$. Blacks were less than $10 \%$ of the nation's senior population, lagging their share of the total population (13\%) [12].

There are nearly eight White older adults for every one Black older adult in the USA, resulting in a major advantage for Whites over Blacks in the current vaccine rollout plan. Unfortunately, this is the reality despite rigorous scientific evidence confirming that coronavirus vulnerabilities vary markedly by race within the US older adult population [13].

Racial disparities exist in coronavirus infection, hospitalization, and death rates because the impacts of the social 
determinants of health - the conditions under which we live, work, and play - vary by race [14]. Due to a legacy of discrimination in all walks of life, we know, for example, the poverty rate for African American older adults is more than twice as high as the poverty rate for all older adults and three times as high as the poverty rate for White older adults [15].

Further, owing to persistently low wages during their prime working years, we know the Black elderly are more likely than their White counterparts to live in sick residential buildings - older deteriorating housing with legacy pollutants like mold, mildew, lead, asbestos, and radon [16]. They are also more likely to live in hyper-segregated neighborhoodsmany proximate to noxious facilities that spew toxic hazards into the natural environment and adversely affect immune systems and overall health of local residents [17-20].

In part, as a function of such dangerous living circumstances that often span the entire life course, Blacks are more likely to experience illness and disability earlier and therefore have shorter years of active life expectancy than Whites [21]. Often this state of affairs stems from comorbidities of multiple chronic diseases and early on-set of age-related challenges that constrain or limit a range of activities of daily living and instrumental activities of daily living, including the ability to see, hear, remember, dress, and interact [22].

In addition, Black older adults are more likely than White older adults to live in multi-generational households, often sharing accommodations with adult biological offspring, grandchildren, and other relatives [23]. Such living arrangements, which also are common among other people of color, heighten the risks of exposure and transmission of the deadly coronavirus.

Available data on vaccine roll out highlight the shortcomings of a race blind approach to the COVID-19 pandemic [24]. Six states-Delaware, Maryland, Mississippi, North Carolina, Tennessee, and Virginia - report COVID-19 vaccination data by race. A recent analysis of the data revealed that, "white people so far have gotten most of the Covid-19 shots" in all six states [25].

Among the six states, North Carolina reportedly has the widest race and ethnic disparity in vaccinations. According to the state's COVID-19 vaccine dashboard, North Carolina had vaccinated 109,799 individuals against the deadly virus as of January 8, 2021 [26]. Whites received $80 \%$ of the vaccinations, while Blacks and other people of color received only $20 \%$. Using their respective shares of COVID-19 cases as benchmarks, Whites (62\% of cases) were grossly over-represented, while Blacks and other people of color (38\% of cases) were grossly under-represented in vaccine coverage. North Carolina dashboard data that are more recent indicate that people of color have received only $10 \%$ of vaccinations in the state. Data from at least 23 other states confirm similar racial disparities in COVID-19 vaccinations [27].
Moving forward, race-specific aspects of disease vulnerabilities must drive our response to the COVID-19 pandemic. A race-conscious plan must ensure both equitable opportunities of access to care and equitable opportunities to receive the vaccines [28, 29]. Failure to quickly develop and implement such a plan will constitute yet another glaring example of systemic racial inequality - an unacceptable outcome in our increasing diverse society.

As Patrick T. Ryan, Chairman and CEO, Press Ganey, notes, "It is imperative that we engage all members of our communities in vaccination programs, and we must keep in mind that each individual's path to vaccine acceptance is shaped by their cultural and life experiences". He continues by noting, "To close vaccination-readiness gaps, healthcare providers must understand and address patient concerns and questions at the individual, community, and population levels" [30].

Further highlighting the need for a race-conscious approach to vaccine rollout, all Blacks - not just the Black elderly-are more likely than Whites to live in multigenerational and often overcrowded households. Therefore, as we have noted elsewhere [31],

The next phase of vaccine administration must take into account the effects of overcrowded living arrangements because of the increased risk of exposure to and spread of Covid-19. In such situations, the priority target for vaccinations must be every individual in the household.

Moreover, such households, not unlike the US population generally, can be comprised of up to five generations - preBoomers, Boomers, and Generations X, Y, and Z-who have varying level of familiarity and access to technology and therefore rely on different channels and sources of information. Consequently, it is strategically important to identify "trusted messengers" for various generations and to devise multi-channel communication strategies to ensure effective dissemination of "trusted messages" about the vaccines across the multiple generations that often live in African American households $[32,33]$. Until we align vaccine rollout with the true demography of high-risk exposure and transmission, the battle to harness the pandemic will continue, and the deadly virus, unfortunately, likely will continue to overcome lives and compromise the economic viability of our nation.

More broadly, to avoid racial miasma in responding to future crisis and in dealing with health disparities generally, the entire healthcare ecosystem must develop greater reputational equity - a demonstrated commitment to dismantling systemic racism in all facets of the profession [34]. To create reputational equity, the profession must first develop a keen understanding of how disruptive demographics are transforming the US workforce, workplaces, and consumer markets [35]; second, demonstrate a willingness to engage in 
courageous listening regarding both the causes and consequences of systemic racism [36-38]; and third, undertake a comprehensive diversity, equity, inclusion, and belonging (DEIB) audit of the entire healthcare ecosystem - a critical review and evaluation policies, procedures, and practices that govern the day-to-day operations of professional schools that train and produce the healthcare workforce as well as the various components of the US healthcare system that rely on the talent the healthcare education, training, and certifying systems produce [39].

Elsewhere, we have produced a reputational equity checklist of evidenced-based strategies, policies, tactics, and procedures for developing reputational equity, which can be used as a guide to fix problems uncovered in the DEIB audit of the healthcare profession [40]. We believe a fully executed DEIB audit using the reputational equity checklist will enable the healthcare profession to continuously recruit, train, employ, nurture, and retain a diverse workforce with demonstrated cultural competencies to care for an increasingly more diverse client base. At the same time, it will enhance the ability of health entities to be better prepared for the next major health crisis.

\section{Declarations}

Ethical Approval This article does not contain any studies with human participants or animals performed by any of the authors.

Conflict of Interest The authors declare no competing interests.

\section{References}

1. Del Rio, C (2020). Covid-19 and its disproportionate impact on racial and ethnic minorities in the United States, Contagion, August, Vol 5, Issue 4. https://www.contagionlive.com/view/ covid19-and-its-disproportionate-impact-on-racial-and-ethnicminorities-in-the-united-states.

2. Wood, D (2020). As pandemic deaths add up, racial disparities persist - and in some case worsen, NPR, September 23. https:// www.npr.org/sections/health-shots/2020/09/23/914427907/aspandemic-deaths-add-up-racial-disparities-persist-and-in-somecases-worsen.

3. Egbert A \& Kristine L, (2020). The Color of Coronavirus: 2020 Year in Review. APM Research Lab, December 21. https://www. apmresearchlab.org/covid/deaths-2020-review.

4. Grace D, Johnson C, \& Reid T (2020). Racial inequality and COVID-19, Capitol Weekly, May 4. https://greenlining.org/press/ opinion-columns/2020/racial-inequality-and-covid-19/?gclid =EAIaIQobChMI3 5yzyteo7gIVA52GCh2PJgYsEAM YASAAEgJQS_D_BwE.

5. Ogedegbe G, Ravenell J, Adhikari S. Assessment of racial/ethnic disparities in hospitalization and mortality in patients with COVID19 in New York City. JAMA Netw Open. 2020;3(12) https:// jamanetwork.com/journals/jamanetworkopen/fullarticle/2773538: e2026881.
6. Zelner J, et al. Racial disparities in coronavius disease 2019 COVID-19 mortality are driven by unequal infectio risks. Clin Infect Dis. 2020. https://doi.org/10.1093/cid/ciaa1723/5998295.

7. Silver V et al (2020). Clinical characteristics and outcomes based on race of hospitalized patients with COVID-19 in a New Orleans cohort," Open Fourm Infectious Diseases, Vol.7, Issue 9, September. https://academic.oup.com/ofid/article/7/9/ofaa339/ 5892291.

8. Dooling K (2020). Phased allocation of COVID-19 vaccines. ACIP COVID-19 Vaccines Work Group, December 20. https://www.cdc. gov/vaccines/acip/meetings/downloads/slides-2020-12/slides-1220/02-COVID-Dooling.pdf.

9. Egede LE, Walker RJ. Structural racism, social risk factors, and Covid-19-a dangerous convergence for Black Americans. N Engl J Med. 2020;3838:e77. https://doi.org/10.1056/ NEJMp2023616.

10. Johnson, J, Bonds, J, \& Parnell, A. (2021). Commentary: urgently needed - a racial equity approach to Covid-19 vaccine distribution. The Daily Yonder, January 22. https://dailyyonder.com/ commentary-urgently-needed-a-racial-equity-approach-to-covid19-vaccine-distribution/2021/01/22/

11. Ortman JM, Velokoff VA, \& Hogan H (2020). An aging nation: the older population in the United States. Current Population Reports P25-1140, May. https://time.com/wp-content/uploads/2015/01/ p25-1140.pdf.

12. United States Census (2020). American community survey 5-year data (2009-2019), December 10. https://www.census.gov/data/ developers/data-sets/acs-5year.html.

13. Chatters LM, Taylor HO, Taylor RJ. Older Blacks Americans During COVID-19: race and age double jeopardy. Health Educ Behav. 2020;47:855-60.https://doi.org/10.1177/ 1090198120965513.

14. Gulzar, S H, et al. (2020). The detrimental impact of theCOVID-19 crisis on health equity and social determinants of health," Journal of Public Health Management \& Practice, Vol 26,Issue 4 July/August. https://journals.1ww.com/jphmp/FullText/2020/07000/The Detrimental_Impact_of_the_COVID_19_Crisis_on.6.aspx.

15. Johnson J H Jr. \& Lian H (2018), Vulnerable African American older adults: the challenge of aging in place, Journal of Housing for the Elderly, https://www.researchgate.net/publication/323506390 Vulnerable_African_American_Seniors_The_Challenges_of_Aging in_Place.

16. Allen J (2020). 'Sick buildings' add to COVID-linked inequity, Coastal Review Online, December 14. https://www.coastalreview. org/2020/12/sick-buildings-add-to-covid-linked-inequity/.

17. Fitzgerald S (2020). Segregated neighborhoods may not be good for cognitive health, Neurology Today, June 18. https://journals. lww.com/neurotodayonline/fulltext/2020/06180/living_in_ racially_segregated_neighborhoods_may.9.aspx.

18. Villaroosa, L (2020). Pollution is killing Black Americans. This community fought back. The New York Times Magazine, July 28. https://www.nytimes.com/2020/07/28/magazine/ pollution-philadelphia-black-americans.html.

19. Crane M (2019). Low-income, Black neighborhoods still hit hard by air pollution, Ohio State News, August 10. https://news.osu.edu/ low-income-black-neighborhoods-still-hit-hard-by-air-pollution/.

20. Dey T, Dominici F. Covid-19, air pollution, and racial inequity: connecting the dots. Chem Res Toxicol. 2020. https://doi.org/10. 1021/acs.chemrestox.0c00432.

21. Freedman V, Spillman B. Active life expectancy in the older adult population, 1982-2011: differences between Blacks and Whites persisted. Health Aff. 2016;35:8 https://europepmc.org/article/ PMC/5240930.

22. Gupta R, Agrawal R, Bukhari Z, Jabbar A, Wang D, Diks J, et al. Higher comorbidities and early deaths in hospitalized African American patients with Covid-19. BMC Infect Dis. 2021;21:78 
https://bmcinfectdis.biomedcentral.com/articles/10.1186/s12879021-05782-9.

23. Graham, J (2020). Why Black aging matters, too," Kaiser Health News, September 3. https://khn.org/news/why-black-agingmatters-too/.

24. Jean-Jacques, M \& Bauchner, H (2021). Vaccine distributionequity left behind? Journal of American Association, Vol 325, March 2. file:///C:/Users/johnsonj/Downloads/ jama_jeanjacques_2021_ed_210007_1614619866.67294.pdf.

25. Livingston S (2021). Most Covid vaccines are going to White people, even though the pandemic has ravaged communities of color, Business Insider, January 9. https://www.businessinsider.in/ science/health/news/most-covid-19-vaccines-are-going-to-whitepeople-even-though-the-pandemic-has-ravaged-communities-ofcolor/articleshow/80176282.cms.

26. NCDHHS Covid-19 response dashboard case demographics. https://covid19.ncdhhs.gov/dashboard/cases-demographics.

27. Halsey, $G$ (2021). Racial disparities in COVID-19 vaccination: data from 23 states. Patient Care, February 5. https://www. patientcareonline.com/view/racial-disparities-in-covid-19vaccination-data-from-23-states.

28. Thomas SB, Quinn SC, Butler J, Fryer CS, \& Garza MA, (2011). Toward a fourth generation of disparities research to achieve health equity, the Annual Review of Public Health, Vol 32, January 3. https://buildingtrustumd.org/sites/default/files/4th_generation_ thomas2011.pdf. Focus need to address racial disparities

29. Bollyky TJ, Gostin LO, \& Hamburg MA (2020). The equitable distribution of COVID-19. therapeutics and vaccines. Journal of American Medical Association, Vol 323, May 7. https:// jamanetwork.com/journals/jama/fullarticle/2765944\%2D\% 2Dequitable.

30. Press Ganey (2021). Vaccine hesitancy and acceptance: data segmentation helps address barriers. Press Ganey White Paper, pressganey.com, February 4. https:/www.pressganey.com/ resources/white-papers/vaccine-hesitancy-and-acceptance?s= White_Paper-PR.

31. Johnson JH, Bonds JM, \& Parnell AM (2021). Commentary: prioritize high risk demographics in vaccine rollout, The Daily Yonder, February 11. https://dailyyonder.com/commentaryprioritize-high-risk-demographics-in-vaccine-rollout/2021/02/11/.

32. Kritz F (2020). Trusted messengers, trust messages: how to overcome vaccine hesitancy. National Public Radio, December 24. https://www.npr.org/sections/health-shots/2020/12/24/948776228/ trusted-messengers-trusted-messages-how-to-overcome-vaccinehesitancy.

33. Eldred SM (2020). Trusted messengers may help disenfranchised communities overcome vaccine hesitancy. Kaiser Health News, December 17. https://khn.org/news/article/trusted-messengersmay-help-disenfranchised-communities-overcome-vaccinehesitancy/

34. Johnson JH and Bonds JM (2021). Does your firm have reputational equity? Journal of Business and Social Science Review, Vol 1, November. https://jbssrnet.com/wp-content/uploads/2020/12/1. pdf.

35. Johnson JH and Parnell AM (2019). Seismic shifts. Business Officer Magazine, July/August. https://businessofficermagazine. org/features/seismic-shifts/

36. Johnson JH and Bonds JM, (2020). Leading, managing, and communicating in an era of certain uncertainty. Kenan Institute of Private Enterprise White Paper, August. https://kenaninstitute.unc. edu/wp-content/uploads/2020/08/Leading-Managing-andCommunicating.pdf.

37. Subotnik D (1998). What's wrong with critical race theory: reopening the case for middle class values. Cornell Journal of Law and Public Policy, Vol 7, Spring. https://scholarship.law. cornell.edu $/$ cgi $/$ viewcontent.cgi?article $=1238 \&$ context $=$ cjlpp

38. Butcher J and Gonzalez M (2020). Critical race theory, the new intolerance, and its grip on America. The Heritage Foundation, December 7. https://scholarship.law.cornell.edu/cgi/viewcontent. cgi?article $=1238 \&$ context $=$ cjlpp.

39. Alexander GR, Johnson JH (2021). Disruptive demographicstheir effects on nursing demand, supply, and academic preparation, Nursing Administration Quarterly, Vol 45. https://journals.lww. $\mathrm{com} / \mathrm{naqjournal} / \mathrm{Abstract} / 2021 / 01000 / \mathrm{Dis} r u p t i v e$ Demographics_Their_Effects_on_Nursing.10.aspx.

40. Johnson JH, Alexander GR, \& Bonds JM (2021), Establishing reputational equity for the nursing profession. Nurs Healthcare Int J 5, January 26. https://medwinpublishers.com/NHIJ/establishingreputational-equity-for-the-nursing-profession.pdf.

Publisher's Note Springer Nature remains neutral with regard to jurisdictional claims in published maps and institutional affiliations. 